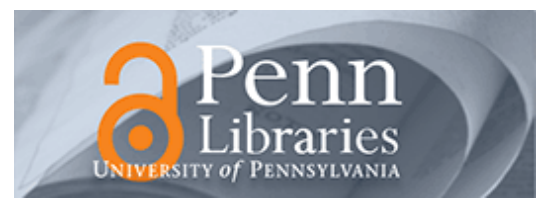

University of Pennsylvania

ScholarlyCommons

Business Economics and Public Policy Papers

Wharton Faculty Research

$10-2016$

\title{
The Opaqueness of Structured Bonds: Evidence from the U.S. Insurance Industry
}

Sojung Carol Park

Jean Lemaire

University of Pennsylvania

Xiaoying Xie

Follow this and additional works at: https://repository.upenn.edu/bepp_papers

Part of the Business Commons, Economics Commons, and the Public Affairs, Public Policy and Public Administration Commons

\section{Recommended Citation}

Park, S., Lemaire, J., \& Xie, X. (2016). The Opaqueness of Structured Bonds: Evidence from the U.S. Insurance Industry. The Geneva Papers on Risk and Insurance - Issues and Practice, 41 (4), 650-676. http://dx.doi.org/10.1057\%2Fs41288-016-0021-4 


\title{
The Opaqueness of Structured Bonds: Evidence from the U.S. Insurance Industry
}

\author{
Abstract \\ It has been argued that the opaqueness of structured bonds, such as mortgage-backed securities, asset- \\ backed securities and collateral debt obligations, was one of the major causes of the recent financial \\ crisis that started in late 2007. We analyse the evolving nature of information asymmetry inherent in \\ various types of structured bonds by examining the U.S. insurers' assets. We show that, prior to 2004 , \\ structured bonds were not associated with greater information asymmetry; however, holding more multi- \\ class structured bonds, especially privately placed bonds, increased the information asymmetry when \\ evaluating insurers' assets post-2004. The effect of information asymmetry was more significant with life \\ insurers than with non-life insurers. In addition, by investigating the rating grades of such structured \\ bonds, we find that the market views higher-grade, privately placed, multi-class structured bonds as \\ having the highest information asymmetry among all types of structured bonds post 2004, an effect \\ which is, again, more significant with life insurers. This result shows that structuring complexities and \\ unreliable ratings make structured bonds more opaque than just securitisation itself.
}

\section{Keywords}

structured bonds, information asymmetry, insurance, bid-ask spread, financial crisis

Disciplines

Business | Economics | Public Affairs, Public Policy and Public Administration 
The Opaqueness of Structured Bonds: Evidence from the U.S. Insurance Industry

\author{
Sojung Park* \\ Assistant Professor of Finance \\ Mihaylo College of Business and Economics \\ California State University, Fullerton \\ Fullerton, CA 92834-6848, USA \\ Email: sopark@fullerton.edu \\ Phone: (657) 278-3754 \\ Fax: (657) 278-2161 \\ and
}

\title{
Xiaoying Xie
}

Assistant Professor of Finance

Mihaylo College of Business and Economics

California State University, Fullerton

Fullerton, CA 92834-6848, USA

Email: xxie@,fullerton.edu

Phone: (657) 278-5389

This version: 01-03-2011

\section{* Corresponding Author}




\begin{abstract}
It has been argued that the opaqueness of structured bonds such as Mortgage-Backed Securities (MBS), Asset-Backed Securities (ABS), and Collateral Debt Obligations (CDOs) was one of the major causes of the recent financial crisis that started in late 2007. In this article, we analyze the evolving nature of the opaqueness of structured bonds by examining U.S. insurers' assets from a capital markets perspective. We show that, before 2005, the market did not view structured bonds as opaque investments; however, after 2005, the market began to perceive multi-class structured bonds, especially private bonds, as opaque assets. In addition, by investigating the rating grades of such structured bonds, we find that the market views lower-grade, private, multiclass structured bonds as the most opaque assets. Additionally, publicly traded multi-class structured bonds with superior ratings are also considered opaque. This result provides a useful foundation for the reform of credit rating agencies.
\end{abstract}

Keywords: Structured Bonds; Opaqueness; Insurance; Financial Crisis 


\section{Introduction}

The burst of the latest real estate market bubble in 2007 soon turned into a liquidity and credit crisis in financial markets. Many papers point out that one of the most important factors that caused the crisis was the opaqueness of structured bonds, such as Mortgage-Backed Securities (MBS), Asset-Backed Securities (ABS), and Collateral Debt Obligations (CDOs) (e.g., Dionne, 2009; Harrington, 2009; Scott and Taylor, 2009; Caprio, Demirgüç-Kunt, and Kane, 2010; Ryan, 2008). Yet, little research has been done to empirically investigate such products and understand the nature of their opaqueness. Previous literature, such as Flannery, Kwan, and Nimalendran (2004) and Zhang, Cox and Van Ness (2009), investigates the opaqueness of banking firms' assets and the opaqueness of asset portfolios and underwriting liabilities of insurance companies. However, these papers do not distinguish structured bonds from other corporate bonds and government bonds in their analyses.

The insurance industry, as an important sector of the financial services industry, has been a big investor in structured bonds (Liebenberg, Colquitt, and Hollans, 2010; IMF, 2008; Manconi, Massa, and Yasuda, 2010). Some big insurance companies even fell into financial trouble because of heavy investment in such bonds. ${ }^{1}$ The lack of empirical research on the opaqueness of structured bonds, the importance of structured bonds for insurance firms, and the rich data available for the U.S. insurance industry have prompted us to examine the opaqueness of

${ }^{1}$ For example, Scottish Re (U.S.) Inc. was put under supervision in January 2009 by the Delaware Insurance Commissioner, mainly because of its declining asset values from residential mortgage backed securities. Before running into financial trouble, as of December 31, 2007, MBSs and CMOs (collateralized mortgage obligations) constituted approximately $19.3 \%$ of the firm's invested assets. 
structured bonds in this article, which extends the existing literature to provide empirical evidence of the opaqueness of structured products.

The volume of literature on analyzing the causes and consequences of the 2007-2008 financial crisis has been rapidly growing. One such cause, the declining value of subprime mortgage-related assets, was the apparent trigger for the recent financial turmoil. Therefore, one side of the current literature discusses why the proportion of subprime mortgages rapidly increased, why the delinquencies of mortgages rose, why financial institutions securitized mortgages, why there were high demands for the structured bonds, and so forth (e.g., Wilmarth, 2009; Krohn and Gruver, 2008; Coleman, LaCour-Little, and Vandell, 2008). These papers usually point out the lax underwriting standards; a long-lasting, low interest rate in the 2000s; competitive pressure for high yields; errors made by rating agencies in risk modeling; and greedy participants in the financial market as the causes of the rapidly grown mortgage-backed securities, along with other changing institutional, political, and regulatory environments after the early 2000s.

The other side of the literature investigates how the relatively small size of subprime mortgages losses can be amplified into a worldwide financial crisis (e.g., Murphy, 2008; Hellwig, 2009; Schwarcz, 2009). The estimated loss in subprime mortgage-backed-securities was about $\$ 500$ billion dollars, which is smaller than the technology bubble loss in 2000 (Hellwig, 2009). These papers argue that lost credibility in the structure process (notably the credibility of rating agencies), financial institutions' high leverage, and opaqueness of the structure process are the causes of this amplification. This raises an empirical question of how opaque these structured products are to the market. Does the market take into consideration the opaqueness of such assets when valuing a firm? So far, systematic empirical research on these questions has been lacking. 
In the past decade, the growing popularity of securitizing and structuring mortgagerelated products has allowed mortgage originators to share and transfer the housing price and credit risk among various investors: banks, insurance companies, hedge funds, mutual funds, and pension funds. However, the spreading and sharing of risks have been done in very complex and opaque ways. There are two related but different transparency issues. One is the opaqueness of off-balance sheet securitization, which makes the issuers opaque, and the other is the opaqueness of structured bonds, which makes the investors opaque.

Assessing the risks of issuers is particularly difficult because many use off-balance sheet entities. Risks are technically transferred through quasi-separated conduits and Structured Investment Vehicles (SIVs). However, since the issuers are still responsible for the liquidity risk of off-balance sheet entities, the risks are not completely transferred. In reality, the degree of risk retention is continuous from complete risk transfer to almost full risk retention, and the information on the degree of risk retention is not fully disclosed. ${ }^{2}$ Cheng, Dhaliwal, and Neamtiu (2010) test the opaqueness of securitization to the issuers and find that off-balance sheet securitization increases the opaqueness of the issuers.

The other source of opaqueness of structured bonds is the opaqueness of the structured bond itself. The nature of the structure process, such as pooling, structuring, and re-structuring, makes it extremely difficult to track the impact of mortgage loan losses on the losses of final structured products. It becomes even harder to estimate the increased risks when structured bonds are part of the underlying assets of other structured bonds such as CDOs. Furthermore, the most complicated CDOs are only sold through private placements, where only registered investors can

\footnotetext{
2 There are two financial reporting techniques for securitization: sales (off-balance sheet) and secured borrowing (on-balance sheet). When a firm uses the off-balance sheet technique, the balance sheet of the issuers does not fully disclose the recourse obligation, servicing requirements, and, of course, the implicit responsibility arising from reputation management.
} 
review the details of the deal. ${ }^{3}$ As a result, investment in such assets tends to increase the opaqueness of a firm to investors.

Dealing with the opaqueness of structured bonds has become a focus of insurance regulation since start of the recent crisis. The National Association of Insurance Commissioners (NAIC) formed a Rating Agency Working Group of the NAIC Financial Condition Committee (hereafter "the group") on February 11, 2009. The group has conducted a comprehensive evaluation of state insurance regulatory use of the credit ratings on structured securities and municipal bonds provided by nationally recognized statistical rating organizations, including Standard \& Poor's, Moody's, Fitch, DBRS, A.M. Best, and Realpoint. The group recommends developing alternative methodologies for assessing structured security risks and reducing regulators' reliance on credit ratings, which the group views to be less than reliable for various reasons. Additionally, the group recommends the development of standards, greater standardization of definitions, greater consistency in the agreements used for structured securities, and so forth (McRaith et al., 2010).

Given the importance of structured bonds in insurance companies' solvency and performance, it is important to investigate several matters: how opaque the structured bonds are to insurance companies' investors; when the market begins to view such investments as opaque assets; what kind of structured bonds make insurance companies' balance sheets more opaque and risky; and whether credit rating can adequately reduce the opaqueness of such products. Therefore, the goal of this paper is to empirically address the opaqueness of different types of structured bonds in insurance companies' assets, as well as their impacts on the valuation of these companies.

\footnotetext{
${ }^{3}$ The complexity of CDOs and CDO squared are well described in Mason and Rosner (2007).
} 
We explore the opaqueness of structured bonds by using data from the insurance industry for several reasons. First, we can better estimate the opaqueness of structured bonds by using homogenous insurance companies without being contaminated by cross-industry effects. For instance, banks are both investors and issuers of structured bonds. Therefore, both the opaqueness of off-balance sheet securitization and the opaqueness of the product itself exist. Hedge funds and investment banks are unregulated; therefore, they tend to hold riskier tranches of structured bonds than insurers. This systemic difference among financial institutions may create noise in empirical estimations. Insurers, on the other hand, are mostly involved in structured bond transactions as investors and not as originators. As a result, we can estimate more accurately the pure opaqueness of the structured bonds themselves without dramatic contamination from opaque off-balance sheet financial reporting. ${ }^{4}$

Secondly, insurance companies are traditionally one of the largest investors of mortgagebacked securities, along with pension funds, hedge funds, and banks (IMF, 2008; Manconi, Massa, and Yasuda, 2010). The long duration of insurers' liability and the relatively long terms of mortgage-backed securities make insurers the ideal investors for mortgage-backed securities. Furthermore, AAA- and AA-rated bonds with higher yields than other corporate bonds or T-bills are very attractive options to insurers whose investment options are limited and strictly regulated by the NAIC. As a result, studying the opaqueness of structured bonds will provide practical reference for insurance regulators, customers and investors.

Lastly, insurance companies are a homogenous group in terms of financial reporting. All insurance companies need to report to the NAIC. The reported structured bonds-related data is

\footnotetext{
${ }^{4}$ AIG and monoline insurers are exceptions because they were also involved in the crisis by "insuring" mortgagerelated securities. We conduct robustness tests by singling out these insurers, which does not change our results.
} 
therefore standardized and more detailed. The standardized NAIC database provides holding information on publicly traded and privately placed single-class and multi-class structured bonds. In addition, it provides rating information for multi-class structured bonds, which enables us to conduct further analysis of the effectiveness of rating on reducing the opaqueness of such products.

In this paper, we first examine the amount of structured bonds held by insurance companies during the ten-year period from 1998 to 2008. Secondly, we investigate whether structured bonds are opaque to evaluate for investors by using a sample of publicly traded life-health (L/H) and property-casualty $(\mathrm{P} / \mathrm{C})$ insurance companies. Specifically we explore the effects of structured bond holdings on the bid-ask spread and analysts' earnings forecast dispersion by controlling for other opaqueness factors of assets and liabilities and market microstructure factors. The analysis is conducted for two sub-periods: from 1998 to 2004, when structured products are less complicated and not as prevalent in the market; and from 2005 to 2008, when the market observed a proliferation of such products. In this way, we can understand to what extent the increase in informational uncertainty regarding insurance companies during the financial crisis is associated with structured bond holdings. In addition, we investigate whether credit ratings of structured bonds carry useful information and reduce the opaqueness to the investors.

The rest of this paper is organized as follows. In the next section, we review the complexity of structured bonds and structured bond holdings in insurers' assets. We then describe our data and methodology, followed by presenting the empirical results. The last section concludes the paper.

\section{Structured Bonds}


"Structured" finance generally refers to financial products created by pooling various underlying risks (such as mortgage loans or auto loans) and slicing them into different "tranches," a French word for "slice." For example, typical Residential Mortgage-Backed Securities (RMBS) are created in the following way: issuers, typically government-sponsored enterprises (GSEs) such as the Federal National Mortgage Association (Fannie Mae), the Federal Home Loan Mortgage Corporation (Freddie Mac), and the Government National Mortgage Association (Ginnie Mae), first acquire mortgage loans from mortgage originators, then pool the mortgage loans, securitize them into bonds, and sell them to investors. If the asset pools are not sliced, the losses from underlying assets simply "pass-through" to the final products, and they are called pass-through MBS. By turning the illiquid cash flows into tradable bonds, securitization provides a new way to sell loans and enhances the liquidity of the housing market, thus making homeownership more affordable.

Securitization, then, has evolved into a more creative way of structuring. Issuers slice the pools into several—at least three—subordinated tranches with different risks. The highest quality tranche, the senior tranche with the AAA rating, gets the lowest return. The next tranche, at the mezzanine level, is usually rated A- to BBB, and the rest is equity tranche (or "toxic waste"), which is non-rated. The cash flows from underlying assets first pay off the senior level, then the mezzanine, and so on. With this structure, the equity level absorbs most of the losses.

Structured bonds are not standardized. Some are structured by default risks, while others are structured by prepayment risks. Furthermore, tranches often include more sophisticated features such as interest-only strips and principal-only strips. RMBS are backed by residential mortgage loans, and CMBS are backed by commercial property mortgage loans. Similarly, the underlying assets of ABS may consist of auto loans, credit card loans, student loans, equipment loans, etc. 
Issuers sell the senior tranche to buyers, and then recycle the less popular mezzanine and equity tranches by using them as underlying assets for other structured bonds called CDOs.

Unlike MBS, CDOs pool various risks, including mortgages, corporate bonds, auto loans, credit card loans, and other structured bonds. By pooling risks that are considered to be not highly correlated and by adding credit default swap (CDS) or bond insurance on top of them, the risks of CDOs - which consist of bad-quality underlying assets - are considered to be significantly lowered. As a result, the default probabilities of CDOs were considered fairly low. (Mason and Rosner, 2007). CDOs, the most complex structured bonds, are only sold through private placement with confidentiality. The process does not stop there. The mezzanine and equity trenches of CDOs are again sold and repackaged to make CDO-squared. Figure 1 presents the growth and increased complexity of structured bonds. CDO issuance increased from 68 billion dollars in 2000 to 521 billion dollars in 2006. Furthermore, the complexity of CDO increased over time. In 2000, only 1.5 percent of underlying assets of CDOs were structured bonds, but the number jumped to 63 percent in 2005 .

Securitization separates mortgage originators and investors. By doing so, mortgage originators have less incentive to screen the quality of risks and monitor them. The increasing profits generated through securitization attracted non-agency institutions like Wall Street investment banks into this business. GSEs originally only acquired "qualified" good-risk mortgages, but non-agency issuers accepted high-risk mortgages as well. As a result, toxic assets like subprime mortgages and Alt-As (Alternative A-paper) $)^{5}$ flooded into the underlying asset pools of structured products. This change occurred very quickly. The total amount of outstanding subprime and Alt-A MBS was 125 billion dollars in 2000, which accounted for four percent of

\footnotetext{
${ }^{5}$ A type of U.S. mortgage, the risk level of which lies between prime loans and subprime loans.
} 
the total MBS outstanding; the number grew to 1.6 trillion dollars in 2007, which was 25 percent of the total MBS outstanding (Gorton, 2009). What is even worse is that these toxic assets were first securitized as MBS, and then some of them flooded into the most complex CDOs. UBS Bank examined 420 CDOs that had structured bonds as collaterals and found that 83 percent of the residential MBS in CDOs were subprime and Alt-A (Gorton, 2009). ${ }^{6}$

With the fanatic pace of growth and the complexity of structuring, the most sophisticated rating agencies are the only ones left that could potentially or still attempted to estimate the risk of structured bonds. As a result, the investors of such products relied more than ever on bond ratings, rather than trying to understand the risk of underlying assets. Institutions that held structured bonds also used the rating information to value their assets. Unfortunately, even the most sophisticated rating agencies failed to catch up with the winds of change and provide quality estimation of the risks. In fact, the close relationship between credit rating agencies and Wall Street bond issuers may have led them to engineer the risks of the highest senior tranche right above the AAA boundary line, making the portfolio less resistant than expected to the default risk of underlying assets. The series of rating downgrades during the 2008-2009 period has raised questions about the credibility of rating agencies. Many pointed out that the market's dependency on rating agencies and these agencies' seriously undermined credibility contributed to the prolonged financial crisis (Caprio, Demirgüç-Kunt, and Kane, 2010). As a result, the newly enacted Dodd-Frank Act in July 2010 imposed new requirements and oversights on credit rating agencies. This phenomenon also makes it interesting to test if the market fully trusts the rating grades of structured bonds provided by such agencies, a test which should shed some light on the necessity of rating agency reform.

\footnotetext{
${ }^{6}$ Official data on total subprime and Alt-A MBS exposures in CDOs are not available because all CDOs are privately placed.
} 


\section{Structured Bonds in Insurers' Assets and Hypotheses Tested}

Insurance companies, especially life insurance companies, are traditionally major purchasers of MBS. Long-term bonds are a good match for the long-term liabilities of life insurance companies. Although there are prepayment risks, the most common type of residential mortgage loan is a 30year loan. Accordingly, typical MBS also has long maturity on average. ${ }^{7}$

In addition, a period of record low interest rates following a high-interest rate period presents a big challenge for life insurance companies, because the guaranteed rate of return for insurance products (made at the time when interest rate was high), such as permanent life insurance products and annuities, is higher than the actual interest rate. The low interest rate, combined with extended life expectancy, increases insurers' demand for investment products with higher yields. Structured bonds provide higher yields than other corporate bonds or treasury bonds but still have the same AAA ratings, which technically do not increase the amount of risk-based capital of an insurance company. ${ }^{8}$ Given the strict investment guidelines imposed by the NAIC, AAA- and AA-rated structured bonds that can comfortably fall within the NAIC-1 rating become very attractive investment options for insurance companies. According to Goldman Sachs' estimation, insurers held about 26 percent of subprime exposures ( $\$ 84$ billion), second only to the banks' 39 percent of subprime exposures (\$127 billion) (IMF, 2008).

Table 1 shows the structured bond investment information for the life-health and the property-casualty industries over the 1998-2008 period. Structured bonds include both singleclass $\mathrm{MBS} / \mathrm{ABS}$ and multi-class $\mathrm{MBS} / \mathrm{ABS} / \mathrm{CDOs}$. Single-class bonds are non-sliced pass-

\footnotetext{
${ }^{7}$ According to Vink and Thibeault (2008), the average MBS matures in just over 27.7 years. They use non-U.S. MBS data only.

${ }^{8}$ The typical coupon rate for AAA-rated CDOs is about LIBOR $+26 \mathrm{bps}$, LIBOR +75 bps for A-rated CDOs, LIBOR+180 for BBB-rated CDOs, and LIBOR+475 for BB-rated CDOs (Lucas, Goodman and Fabozzi, 2006).
} 
throughs, and multi-class bonds represent the rest of the structured products. Insurers' investments in multi-class structured bonds more than doubled from 1998 to 2006. In total, the insurance industry (both $\mathrm{L} / \mathrm{H}$ and $\mathrm{P} / \mathrm{C}$ ) invested about $\$ 444$ billion in structured bonds in 1998, and that number increased to $\$ 1.1$ trillion in $2006 .^{9}$

The table shows that in the life-health industry, the percentage of firms with investment in single class structured bonds (57\% in 1998 and 68\% in 2005) and multi-class structured bonds (42\% in 1998 and 54\% in 2005) has increased over time. When looking at the structured bond holdings as a percentage of total assets for a median firm in this industry, we find that the percentage of single-class structured bonds has not changed much over time. However, the percentage of multi-class structured bonds has increased dramatically and reached double digits during the 2005-2008 period (from an average 8.95\% during 1998-2004 to an average 11.27\% during 2005-2008).

The percentage of property-liability insurers that hold structured bonds is not as high as that of life-health insurers and shows no sign of increase over time. For $\mathrm{P} / \mathrm{C}$ insurers with structured bond investments, the median percentage of structured bond holdings to total assets stably increases over time. The percentage reached more than six percent during the $2005-2008$ period for both single-class and multi-class bonds.

In sum, life-health insurance companies hold more structured bonds than property-casualty insurance companies do in terms of both absolute amount and percentage of assets, which is consistent with the asset-liability duration-matching incentive of life insurers.

The apparent downside for insurance company investment in structured bonds is the complexity and opaqueness of such bonds. The complicated nature of structured products makes

\footnotetext{
9 These numbers are in 2005 dollars.
} 
it very difficult for insurers to understand and value them. Although a higher yield with the NAIC-1 rating is very attractive, some insurers could be reluctant to take this option because they are not capable of understanding these products and risks associated with them. This argument is consistent with that of Liebenberg, Colquitt, and Hollans (2010), who find that a significant number of insurers do not invest in RMBS at all; and Baranoff and Sager (2009), who find that many life insurers fail to adjust capital to accommodate the increased risk of structured bonds.

The difficulty of valuing structured bonds is not limited to structured bond purchasers; it could be even more difficult for investors to value insurance companies that have structured bond holdings. Although all insurers in the U.S. report total structured bond holdings in Statutory Annual Statements, the reported value is still opaque due to the aforementioned nature of these products. Private multi-class structured bonds are probably the most opaque to investors because they are highly structured and tailored, which makes it almost impossible for outsiders to understand their real risk by simply looking at the reported values. Borrowers and lenders negotiate the lending terms and conditions, and lenders have a right to monitor borrowers closely, but the deal information is usually not disclosed to other parties. ${ }^{10}$ On top of that, the most complex type of multi-class structured bonds, CDOs, are only issued in over-the-counter markets. We therefore hypothesize that holding more structured bonds, particularly privately placed multiclass bonds, increases the information gap between insurers and their investors, which increases the opaqueness of insurance firms.

\footnotetext{
${ }^{10}$ Publicly traded companies may disclose more information on private bonds to their investors in their SEC (Securities and Exchange Commission) reports, but the details are not standardized, and the disclosure level is up to individual companies.
} 
As described above, insurance company investments are subject to investment guidelines from the NAIC, which restricts their investments in non-graded or risky bonds. Investments in structured bonds should also follow these same rules. The NAIC used to rely on credit ratings from rating agencies for publicly traded bonds and apply their own risk ratings for privately placed bonds (Kwan and Carleton, 2004) ${ }^{11}$. Given the proposed change by the NAIC about using credit ratings for structured bonds after the financial crisis, it will be interesting to investigate whether the existing rating system provides useful information to the market. As such, we examine the opaqueness of structured bonds that are NAIC-1 rated and those that are rated NAIC-2 and below. We predict that if the market believes in the credit ratings, then structured bonds (public or private) with an NAIC-1 rating will be less opaque, while those with below an NAIC-1 rating will add opaqueness to insurance stocks. However, if the market has less confidence in the public rating agencies, the publicly traded NAIC-1 rating bonds will not be as transparent to the market as their ratings indicate.

\section{Data and Methodology}

\section{Data and Sample Selection}

The sample studied in this paper includes publicly traded U.S. insurers. The initial list of publicly traded insurers is drawn from COMPUSTAT and CRSP (Center for Research in Securities Prices). Firms traded on the NYSE, AMEX, or NASDAQ with an SIC code identifying them as insurance companies are included in the study (SIC code: 6311-6399, excepting agencies and

\footnotetext{
${ }^{11}$ Moody's AAA/AA/A and S\&P AAA/AA/A correspond to an NAIC-1 rating. Moody's BAA and S\&P BBB and lower ratings correspond to an NAIC-2 rating and lower.
} 
brokers). ${ }^{12}$ Our sample period is January 1, 1998 through December 31, 2008. This initial sample is matched with the NAIC database using company names, licensed states, and subsidiary information.

We collect firms' structured bonds data and other financial information primarily from the NAIC database because only limited information is available from COMPUSTAT as compared to the NAIC. Our study is at the group and unaffiliated single firm level. We consolidate a firm's property-casualty and life-health operations by group code. To guarantee that our sample is restricted to insurance firms only, we exclude companies whose consolidated total assets from the NAIC is less than 50 percent of COMPUSTAT's total assets. The final sample includes 205 firms with 1134 firm-years of data.

We extract data on bid-ask spread, stock price, trading volume, and stock returns from CRSP. We also use the $\mathrm{I} / \mathrm{B} / \mathrm{E} / \mathrm{S}$ database to obtain the number of analysts and dispersion in analysts' earnings forecasts.

\section{Opaqueness Measures}

The first opaqueness measure used in this study is the bid-ask spread. Numerous market microstructure studies provide theoretical and empirical evidence that one rationale for the existence of bid-ask spreads is information asymmetry in the stock market (Bagehot, 1971; Kyle, 1985; and Glosten and Milgrom, 1985). It is argued that market makers post the bid (the price at which a stock can be sold) and ask prices (the price at which a stock can be bought) in such a

\footnotetext{
${ }^{12}$ COMPUSTAT and CRSP have slightly different SIC code records. When either COMPUSTAT or CRSP does not report an insurance SIC code, we check business information manually from the 10-K report available in the SEC's EDGAR database for that year.
} 
way that the expected profit from trades can be zero, despite the fact that informed traders buy or sell stocks only if the trading is profitable for them. In other words, the market maker, who generally cannot distinguish between informed traders and uninformed traders, recovers losses incurred in trades with informed traders through gains in trades with uninformed traders by maintaining the bid-ask spreads. As a result, stocks with higher levels of information asymmetry should have bigger bid-ask spreads.

The relative opaqueness of assets and liabilities of financial institutions has been shown to affect bid-ask spreads in the stock market. Flannery, Kwan, and Nimalendran (2004) adopt bid-ask spreads as opaqueness measures and show that, after controlling for market microstructure factors and other financial characteristics, bid-ask spreads are associated with opaque bank assets, such as bank loans. Zhang, Cox, and Van Ness (2009), by studying publicly traded insurance companies, also show that more opaque underwriting liability results in greater spreads. In this study, we follow previous literature and adopt the following quoted spreads (QSPREAD) as a measure of opaqueness.

$$
\text { QSPREAD }=\operatorname{avg}\left(\frac{\mathrm{Ask}_{\mathrm{t}}-\mathrm{Bid}_{\mathrm{t}}}{\mathrm{MP}_{\mathrm{t}}}\right),
$$

where $A_{s k}$ is daily closing ask price, $\mathrm{Bid}_{\mathrm{t}}$ is daily closing bid price, and $\mathrm{MP}_{\mathrm{t}}$ is the average of Ask $_{t}$ and $\mathrm{Bid}_{\mathrm{t}}$. QSPREAD is an average of daily bid-ask spreads for the first quarter. We use the first quarter data because only annual data is available from NAIC. We link previous yearend NAIC data with the first quarter average bid-ask spreads for the following year.

The second opaqueness measure is analysts' earnings forecast dispersion (DISP). Analysts' earnings forecast dispersion is broadly used as a measure of asymmetric information and 
uncertainty about asset value in many studies (e.g., Flannery, Kwan, and Nimalendran, 2004; Van Ness, Van Ness, and Warr, 2001; Thomas, 2002; Zhang, 2006). If an insurance company's assets and liabilities are opaque, and thus more difficult for analysts to value, the analysts should more often disagree on the forecasts of earnings. Following Zhang, Cox, and Van Ness (2009), we measure analysts' earnings forecast dispersion as the standard deviation of one-year earnings forecasts divided by the median forecast. Stocks with fewer than two analysts following are excluded when we use DISP as an opaqueness measure.

\section{Structured Bond Variables}

Schedule D, Part 1A Section 2 of the NAIC annual statement provides the aggregate value of publicly and privately traded bonds and their breakdown to non-structured bonds, single-class structured bonds, and multi-class structured bonds. Our primary interest is in the opaqueness of private and public multi-class structured bonds, which consists of RMBS, CMBS, ABS, and CDOs. The statement also provides the credit rating information of such bonds, which enables us to test whether the damaged credibility of rating agencies increases the opaqueness of rated structured products over time.

\section{Methodology}

We run the fixed effects panel regression to examine the opaqueness of structured bonds in insurers' assets. A robust regression method is adopted to accommodate the appearance of outliers and non-normality issues of data. ${ }^{13}$ We run separate analyses for the period of 1998-2004,

\footnotetext{
${ }^{13}$ Robust regression method uses an iteratively reweighted least squares estimation method. It assigns higher weights to better-behaved observations and can drop extreme cases, e.g., those with Cook's D greater than 1, from the regression. This method can achieve the efficiency of OLS with ideal data and performs substantially better than OLS in non-ideal situations (e.g., data with non-normal errors or outliers) (Hamilton, 2003).
} 
which we call the early period of structured bonds, and the period of 2005-2008, which we call the growing period of the structured bonds. This way, we are able to see whether the market's view of the opaqueness of such products changes over time. In particular, the model specification is as follows:

$$
\begin{aligned}
& O P A Q U E_{i t}=\beta_{0}+\beta_{1} P U B S I N G L E_{t t}+\beta_{2} P_{R I S I N G L E}+\beta_{3} P U B M U L T I_{i t}+\beta_{4} P_{\text {RIMULTI }}+ \\
& +\beta_{5} \text { OOPAQUE } E_{t t}+\beta_{6} \text { PCOPA }_{t t}+\beta_{7} \text { LHOPA }_{t t}+\beta_{8} \text { FINHOLD }_{i t}+\beta_{9} \text { LASSET }_{i t} \\
& +\beta_{10} \text { LEVER }_{i t}+\beta_{11} \text { GROWTH }_{i t}+\beta_{12} L A N A L_{i t}+\beta_{13} L S T D_{i t}+\beta_{14} L V O L_{i t}+\beta_{15} L P R C_{i t} \\
& + \text { firm_dummies }+ \text { year_dummies }+\varepsilon_{i t} \text {, }
\end{aligned}
$$

where

OPAQUE = the average quoted bid-ask spread (QSPREAD) or the analysts' earnings forecast dispersion (DISP)

PUBSINGLE $=$ the ratio of total publicly traded, single-class structured bonds to total assets

PRISINGLE $=$ the ratio of total privately placed, single-class structured bonds to total assets

PUBMULTI = the ratio of total publicly traded, multi-class structured bonds to total assets

PRIMULTI = the ratio of total privately placed, multi-class structured bonds to total assets

OOPAQUE = the ratio of investment in mortgage, real estate, and non-structured private bonds to total assets

PCOPA $=$ the ratio of premiums in long-tail lines, mortgage guarantees, financial guarantees, and credit lines to total premiums

LHOPA = the ratio of premiums in individual life, individual annuity, and credit life to total premiums

FINHOLD = a dummy variable equal to one if an insurer is a financial holding company and zero otherwise. ${ }^{14}$

LASSET $\quad=\log$ of total assets

LEVER $=$ debt to asset ratio

GROWTH $=\log$ of (market value of equity + book value of debt)/book value of asset

${ }^{14}$ Following Egginton et al. (2010), we identify financial holding companies by using the COMPUSTAT segment database and firm 10-K reports. We consider an insurance company a financial holding company if the firm reports any non-insurance financial services segments, such as Asset Management, Financial Products, Investment Management, and Financial Services (with SIC 62XX or NAICS 523XXX). If such information is not available, we refer to a firm's 10-K reports to identify whether the firm has non-insurance financial services business. 
LANAL $\quad=\log (1+$ number of analysts following stock $i$ during year $t)$

LSTD $\quad=\log$ of daily stock return standard deviation

LPRC $\quad=\log$ of closing stock price at the end of the year

LVOL $\quad=\log$ of average daily trading volume

In the regression testing of whether or not the market perceives the differences of opaqueness in multi-class structured bonds with different ratings, we split PUBMULTI into PUBMULTID and PUBMULTIO, and split PRIMULTI into PRIMULTID and PRIMULTIO, where

PUBMULTID $=$ the ratio of NAIC-1 graded publicly traded multi-class structured bonds to total assets

PUBMULTIO $=$ the ratio of NAIC-2 and lower grade publicly traded multi-class structured bonds to total assets

PRIMULTID = the ratio of NAIC-1 graded privately placed multi-class structured bonds to total assets

PRIMULTID $=$ the ratio of NAIC-2 and lower grade privately placed multi-class structured bonds to total assets

The dependent variables of the regressions are the opaqueness measures of insurance firms; that is, the average of quoted bid-ask spread and the dispersion in the analysts' earnings forecast are used as dependent variables.

The key independent variables are the four structured bond holdings variables: PUBSINGLE, PRISINGLE, PUBMULTI, and PRIMULTI. We expect PRIMULTI, the percentage of private multi-class structured bond holdings to total assets, to be strongly positively associated with the opaqueness of the insurance company. We expect that PUBMULTI, the percentage of publicly traded multi-class structured bond holdings to total assets, to have a relationship that is not as strong as PRIMULTI but still positive. PUBSINGLE and PRISINGLE are the proportion of public and private pass-throughs. Pass-throughs are also 
securitized assets, but the risk of their underlying assets is passed through to the final investor, the insurance company; therefore, we do not expect pass-throughs to be more opaque than most of the other assets of the insurance company. PRISINGLE could add opaqueness to an insurer's assets because private bonds, a type of investment analogous to bank loans, can be opaque by nature. It is difficult for public market investors to evaluate borrowers in private placement markets due to information asymmetry, and the deal value is usually too small to secure a public offering. Borrowers and lenders negotiate the lending terms and conditions, but the information is not available to public investors (Cummins, Phillips, and Smith, 2001; Kwan and Carleton, 2004).

The remaining independent variables control for other opaque asset and liability factors, firm characteristics, and market microstructure variables that might be associated with a firm's opaqueness, as shown in the existing literature. We first control for other types of opaque assets of insurance companies (OOPAQUE). Traditionally, investment in mortgage loans and real estate are considered opaque assets of insurance firms, but no empirical evidence shows that such assets add opaqueness to insurance companies (Zhang, Cox, and Van Ness, 2009). Bonds used to be viewed as transparent assets of insurance firms; however, as argued in previous sections, structured bonds, by the nature of their design, are very opaque to the investors, and non-structured private bonds, by the nature of their transactions, could be considered opaque as well. As a result, after singling out the structured bonds, we combine investments in mortgage loans, real estate, and non-structured private bonds as other opaque assets. We do not have strong predictions regarding this variable, since existing literature does not find that these assets are actually opaque. 
Following Zhang, Cox, and Van Ness (2009), we also control for opaque liabilities. Unlike other financial institutions, insurance companies operate with risky liabilities. The degree of uncertainty and information asymmetry varies across lines of business. Certain lines, such as long-tail commercial lines (e.g. worker's compensation or commercial liability lines) are more information intensive and are exposed to higher pricing errors; thus, not only is the proprietary cost high but there is also more opportunity for manipulation. We construct opaque liability variables for the property-liability business (PCOPA) by including the long-tail lines of business, ${ }^{15}$ mortgage guarantees, financial guarantees, and credit insurance. The latter three lines are considered opaque liabilities because the risk and uncertainty of these lines are expected to be higher, as shown by the recent financial crisis. We also classify life-health insurance lines into opaque and transparent lines. During the crisis period, many life insurance companies experienced negative underwriting profits from variable annuities and life insurance products with guaranteed return policy terms. Variable annuities and life products' investment assets are in separate accounts of LH insurers, and their risk usually is not insurers' risk. However, the guarantee feature, which requires insurers to match certain minimum returns under some circumstances, makes these products risky for insurers. Furthermore, the information on the amount of variable products that insurers sold and the amount of obligated guarantee is often not disclosed. The lines of business classification available for LH insurers are industrial life, ordinary (individual) life and annuities, group life and annuities, credit life, and accident and health lines. We expect that most of the variable products with investment features and guarantee

\footnotetext{
${ }^{15}$ We follow the definition of Phillips, Cummins, and Allen (1998), defining the following as long-tail lines: farmowners multiple peril, homeowners multiple peril, commercial multiple peril, ocean marine, medical malpractice, workers' compensation, other liability, product liability, auto liability, aircraft, international, and reinsurance.
} 
options are individual life and annuities lines. Therefore, we classify individual life and annuity as relatively more opaque LH lines of business. We also add credit life to the opaque liability set (LHOPA) because we expect that the rapid changes in the real estate and mortgage market may increase the risk of credit life insurance. As shown by A. M. Best, for financially impaired life companies, individual life, credit life, and individual annuity often dominate these firms' business portfolios (A. M. Best, 2010). As a result, these lines are considered relatively more opaque or risky.

In addition to the three opaque asset and liability variables, we include a control variable for financial holding companies. AIG, one such holding company, suffered huge losses during the recent financial crisis due to CDS transactions conducted by its Financial Products Unit (Harrington, 2009); this fact may indicate that such transactions might have increased the opaqueness of insurance companies during recent years. In fact, insurance regulations prohibit insurance companies from writing CDS (Harrington, 2009), but financial holding companies such as AIG could have such transactions in their non-insurance investment operations. Since the SEC 10-K does not provide standardized complete information on CDS transactions, we proxy it by identifying whether an insurance company is a financial holding company. Following the method used in Egginton et al. (2010), we define FINHOLD equal to one if a firm reports any non-insurance financial services segments such as asset management, financial products, investment management, or financial services, and zero otherwise.

We generally follow Zhang, Cox, and Van Ness (2009) and Flannery, Kwan, and Nimalendran (2004) for other control variables. Both the analysts' forecast dispersion and the bid-ask spreads are affected by a company's uncertainty, so we control the standard deviation of stock returns in the model. The number of analysts is controlled because more analysts may 
reduce the opaqueness. Finally, market microstructure literature reports evidence that trading volume and price are correlated with bid-ask spreads, so we include average trading volume and stock price in the regression. We also control for firm characteristics such as size, debt-to-asset ratio, and market-to-book ratio.

The structured bonds became more complex and became toxic assets when subprime mortgages flooded into the market in recent years. Therefore, we run separate regressions for the periods of 1998-2004 and 2005-2008 in order to examine the increased opaqueness of structured bonds over time.

\section{Empirical Results}

\section{Summary Statistics}

Table 2 presents summary statistics for our sample of publicly traded insurance companies. The quoted bid-ask spread in our sample is 1.27 percent on average. Analysts' earnings forecast dispersion is 0.05 on average. The number of observation of dispersion is smaller than that of the quoted spread because only insurers with at least two analysts are included in the sample.

On the asset side, on average, about 14 percent of insurers' assets are structured bonds, and they are mostly publicly traded. Publicly traded multi-class bonds with an NAIC-1 rating (PUBMULTID), on average, account for 5.68 percent of insurers' assets. The privately traded multi-class structured bonds (PRIMULTI), which are expected to be the most complicated and opaque, on average account for 0.48 percent of insurers' assets, and within this category, about 67 percent have an NAIC-2 to -6 rating (PRIMULTIO) (which accounts for 0.32 percent of insurers' assets). On the liability side, about 55 percent of premiums are from long-tail lines and guarantee lines of business (PAOPA), and 14 percent are from ordinary life, credit life, and 
individual annuity lines of business (LHOPA). About 21 percent of our sample has a financial holding company dummy equal to one.

\section{Regression Results}

\section{Public vs. private structured bonds}

Table 3 presents the regression results testing the opaqueness of public and private structured bonds without considering their ratings. As expected, private multi-class bonds, which include CDOs, have the strongest positive relation with opaqueness of insurance companies during the period of 2005-2008. The coefficients of PRIMULTI and PUBMULTI in both bid-ask spread and dispersion regressions are significantly positive, suggesting that both privately and publicly traded multi-class structured bonds are viewed as opaque assets in 2005-2008. However, the coefficient of publicly traded structured bonds (PUBMULTI) is less than half of that of privately placed structured bonds (PRIMULTI), suggesting that the magnitude of opaqueness is smaller for publicly traded structured bonds. Similarly, private pass-throughs (PRISINGLE) have positive coefficients in 2005-2008 regressions, but the coefficients are smaller than the coefficients of PRIMULTI. Although publicly traded pass-throughs (PUBSINGLE) include mortgage loans as underlying assets, the regression results show that they are rather transparent.

None of the structured bonds variables is significant in the 1998-2004 regressions except for PUBMULTI in the dispersion regression. The toxic assets, such as sub-prime mortgages, flooded into the structured product market beginning in 2005, and the increase in opaqueness of structured products began then as well. The regression results in general suggest that the market did not view structured bonds as opaque assets before 2005 . 
The results for other opaque asset and liability variables indicate that the assets we categorize as opaque (OOPAQUE), such as real estate, mortgage, and non-structured private bonds, are not related to the opaqueness of the insurance company. This result is consistent with the findings in Zhang, Cox, and Van Ness (2009), where they find no correlation between asset composition and the opaqueness of insurance companies. It seems that Zhang, Cox, and Van Ness find no relation between asset composition and the firm opaqueness because they do not single out structured bonds from other types of bonds, whereas in our study, we include separate variables for structured bonds. In addition, their sample period was from 1996-2004, a period prior to the complicated structuring processes and influx of toxic assets, such as subprime mortgages, into the market.

The results for the liability composition suggest that PC long-tail lines and financial guarantee lines (PCOPA) do not increase the opaqueness of the insurance company. While we find no relation on the PC side, the LH line of business variable (LHOPA) is positive and significant in the 2005-2008 bid-ask spread regression, suggesting that the increased uncertainty about the various guarantees provided by insurers for variable products during the recent years (A. M. Best, 2010) could increase the opaqueness of these lines of business.

Results for other covariates, such as market microstructure variables and corporate finance factors, are mostly consistent with existing literature. For example, as a stock has more analysts following it and a lower stock return deviation, it has a smaller bid-ask spread and dispersion. We find that the market-to-book ratio (GROWTH) is insignificant in the 1998-2004 regressions and significantly positive in the 2005-2008 regressions. Zhang, Cox, and Van Ness (2009) also find the growth variable negative and insignificant with their sample. This suggests that the market did not perceive growing insurance companies as more opaque before 2005, but 
that market makers and analysts had informational problems with growing insurers during the unstable economic period.

\section{Rating of structured bonds and their opaqueness}

The NAIC provides rating information on multi-class structured bonds. In Schedule D of the NAIC annual report, both private and public multi-class structured bonds are classified into two categories: Defined MBS/ABS and Other MBS/ABS. Multi-class structured bonds rated NAIC-1 are in the Multi-Class Defined MBS/ABS category, and multi-class structured bonds rated NAIC-2 or below are in Multi-Class Other MBS/ABS category. No rating information is available for pass-through securities. In this section, we test the effects of bond rating on the opaqueness of structured bonds. We include four new variables (PUBMULTID, PUBMULTIO, PRIMULTID, and PRIMULTIO) instead of the two multi-class structured bond variables (PUBMULTI and PRIMULTI) in the regressions.

Most publicly traded bonds are rated by major rating agencies such as Moody’s and S\&P. However, privately placed bonds are not rated by bond rating agencies in many cases (Kwan and Carleton, 2004). Instead, the NAIC provides credit ratings for non-rated private bonds in insurers' assets for solvency regulation purposes. It is expected that weak credit quality bonds have higher risks and thus have positive associations with bid-ask spreads and dispersion. However, this relation may be unclear because NAIC-1 rated bonds could have the same degree of complexity, and the lost credibility of rating agencies and inflated rating grades provided by such agencies may raise investors' doubts about the quality of NAIC-1 rated bonds. As shown in Table 2, most public multi-class structured bonds in insurance companies' assets have an NAIC-1 rating, and two-thirds of private multi-class structured bonds have ratings of NAIC-2 or lower. In this sense, 
it is interesting to examine how the market perceives the opaqueness of structured bonds with different ratings. The regression results are reported in Table 4 .

Private multi-class bonds with NAIC-2 ratings or lower (PRIMULTIO) are shown to be the most opaque assets in the 2005-2008 regressions. Combined with the results of Table 3, it suggests that the opaqueness of private multi-class structured bonds primarily comes from the bonds with high default risks. Interestingly, the results for publicly traded structured bonds reveal a different relation. Public bonds with NAIC-1 ratings (PUBMULTID) increase the opaqueness of insurance companies, whereas public bonds with NAIC-2 or lower ratings (PUBMULTIO) do not have a significant relationship with firm opaqueness. This suggests that the strong ratings provided by rating agencies do not resolve information asymmetry between insurance companies and their investors on the quality of these bonds. Our results provide some evidence that public rating agencies may actually bias their ratings on structured bonds upward and that a reform of the rating agency system is in fact necessary.

\section{Conclusion}

The purpose of this study is to examine the opaqueness of structured bonds from a capital markets perspective by studying publicly traded insurance companies in the U.S. By concentrating on one industry, we can have a more homogeneous sample, which can provide cleaner results than cross-industry studies and is free of dramatic contamination from opaque offbalance sheet financial reporting. This article is the first empirical examination of the frequently discussed problem of structured bond opaqueness, which is considered as one of the important causes of the recent financial crisis. Methodologically, this study is an extension of previous 
works on the opaqueness of insurance companies by Zhang, Cox, and Van Ness (2009) and the opaqueness of bank holding companies by Flannery, Kwan, and Nimalendran (2004).

We first show that insurance companies are one of the major investors in structured bonds. We argue that the opaqueness of structured bonds in insurers' assets will cause market makers and analysts difficulty in evaluating insurance company stocks, thus increasing bid-ask spreads and analysts' earnings forecast dispersion. We hypothesize that the opaqueness of structured bonds increases as the structure becomes more complex and contains more private information. In other words, privately placed and multi-class structured bonds should be more opaque than other types of structured bonds.

The paper finds that publicly traded single-class structured bonds are rather transparent compared to other assets, multi-class structured bonds are more opaque than single-class, and privately placed multi-class structured bonds the most opaque in insurers' assets. Structured bonds are only found to be considered opaque during the 2005-2008 period, when the complexity of bonds increased and toxic assets flooded into the asset pools. This suggests that securitized assets or mortgage related assets themselves are not necessarily opaque. It is the complex structure process and insufficient disclosure of information that make these assets more opaque to investors.

Rating information on the structured bonds should reduce the opaqueness of these assets. However, our results show that strong AAA/AA ratings from rating agencies do not close the information gap; rather, they increase this gap. In contrast, it seems that good rating information on private bonds, which usually are provided by NAIC rather than by rating agencies, reduces the opaqueness. 
Overall, this paper provides strong empirical evidence that structured bonds, especially privately placed multi-class bonds, are opaque to the market and investors. In addition, the opaqueness of publicly traded multi-class structured bonds with strong ratings suggests that firms and regulators should be careful when using rating information provided by the public rating agencies in making their investment decisions, since the market and general investors may perceive the ratings differently. 


\section{References}

A. M. Best. Special report. 2010. U.S. Life/Health. L/H Impairments Hit Decade High On Investment Losses/Pricing.

Bagehot, Walter. 1971. The Only Game in Town. Financial Analysts Journal 27 (2):12-14+22.

Baranoff, Etti G., and Thomas W. Sager. 2009. The Impact of Mortgage Backed Securities on Capital Requirements of Life Insurers in the Financial Crisis of 2007-2008. Geneva Papers on Risk and Insurance - Issues and Practice 34 (1):100-118.

Caprio, Gerard, Asli Demirgüç-Kunt, and Edward J. Kane. 2010. The 2007 Meltdown in Structured Securitization - Searching for Lessons, Not Scapegoats. The World Bank Research Observer 25 (1):125-155.

Cheng, Mei, Dan Dhaliwal, and Monica Neamtiu. 2010. Asset Securitization, Securitization Recourse, and Information Uncertainty. Accounting Review. Forthcoming.

Coleman, Major, Michael LaCour-Little, and Kerry D. Vandell. 2008. Subprime Lending and the Housing Bubble: Tail Wags Dog? Journal of Housing Economics 17(4): 272-290.

Cummins, J. David, Richard D. Phillips, S. Smith. 2001. Derivatives and corporate risk management: participation and volume decisions in the insurance industry, Journal of Risk and Insurance 68(1): 51-92.

Dionne, Georges. 2009. Structured Finance, Risk Management, and the Recent Financial Crisis. Working paper. Available at SSRN: http://ssrn.com/abstract $=1488767$.

Egginton, Jared F., James I. Hilliard, Andre P. Liebenberg, and Ivonne A. Liebenberg. 2010. What Effect Did AIG's Bailout, and the Preceding Events, Have on Its Competitors. Risk Management and Insurance Review, forthcoming.

Flannery, Mark J., Simon H. Kwan, and M. Nimalendran. 2004. Market Evidence on the Opaqueness of Banking Firms' Assets. Journal of Financial Economics 71 (3):419-460.

Glosten, Lawrence R., and Paul R. Milgrom. 1985. Bid, Ask and Transaction Prices in a Specialist Market With Heterogeneously Informed Traders. Journal of Financial Economics 14 (1):71-100.

Gorton, Gary. 2009. The Subprime Panic. European Financial Management 5 (1):10-46.

Hamilton, L. C.. 2003. Statistics with STATA. Version 8, Duxbury Press.

Harrington, Scott E. 2009. The Financial Crisis, Systemic Risk, and the Future of Insurance Regulation. Journal of Risk and Insurance 76 (4):785-819.

Hellwig, Martin F. 2009. Systemic Risk in the Financial Sector: An Analysis of the Subprime-Mortgage Financial Crisis. De Economist 157 (2):129-207.

IMF. April 2008. Containing Systemic Risks and Restoring Financial Soundness. Global Financial Stability Report.

Krohn, Gregory A., and William R. Gruver. 2008. The Complexities of the Financial Turmoil of 2007 and 2008. Available at SSRN: http://ssrn.com/abstract=1282250.

Kwan, Simon, and Willard T. Carleton. 2004. Financial Contracting and the Choice between Private Placement and Publicly Offered Bonds. Working paper, Federal Reserve Bank of San Francisco.

Kyle, Albert S. 1985. Continuous auctions and insider trading. Econometrica 53 (6):1315-1335. 
Liebenberg, Andre P., L. Lee Colquitt, and Harris Hollans. 2010. The Determinants and Potential Effects of Life Insurer Mortgage Backed Securities Exposure. Journal of Insurance Issues 33 (1): 1-30.

Lucas, Douglas L., Laurie S. Goodman, and Frank J. Fabozzi. 2006. Collateralized Debt Obligations: Structures and Analysis, $2^{\text {nd }}$ Ed. Hoboken, NJ: Wiley.

Manconi, Alberto, Massimo Massa, and Ayako Yasuda. 2010. The Role of Institutional Investors in Propagating the Crisis of 2007-2008. UC Davis Graduate School of Management Research Paper No. 04-10. Available at SSRN: http://ssrn.com/abstract=1454831.

Mason, Joseph R. , and Josh Rosner. 2007. How Resilient are Mortgage Backed Securities to Collateralized Debt Obligation Market Disruptions? Working paper. Available at SSRN: http://ssrn.com/abstract=1027472.

McRaith, Michael, James J. Wrynn, Matti Peltonen, Kevin Fry, and Bob Carcano. April 28, 2010. Evaluating the Risks Associated with NAIC Reliance on NRSRO Credit Ratings - Final Report of the RAWG to the Financial Conditions (E) Committee. http://www.naic.org/documents/committees_e_rating_agency_report_adopted_by_e_committee.p df.

Murphy, Austin. 2008. An Analysis of the Financial Crisis of 2008: Causes and Solutions. Available at SSRN: http://ssrn.com/abstract=1295344.

Phillips, Richard D., J. David Cummins, and Franklin Allen. 1998. Financial Pricing of Insurance in the Multiple-Line Insurance Company. Journal of Risk and Insurance 65 (4):597-636.

Ryan, Stephen G.. 2008. Accounting in and for the Subprime Crisis. Accounting Review 83:1605-1638.

Schwarcz, Steven L. 2009. Keynote Address: Understanding the Subprime Financial Crisis. South Carolina Law Review 60 (3).

Scott, Kenneth E. , and John B. Taylor. July 21, 2009. Why Toxic Assets Are So Hard to Clean Up. The Wall Street Journal.

Thomas, Shawn. 2002. Firm Diversification and Asymmetric Information: Evidence from Analysts'forecasts and Earnings Announcements. Journal of Financial Economics 64 (3):373396.

Van Ness, Bonnie F., Robert A. Van Ness, and Richard S. Warr. 2001. How Well Do Adverse Selection Components Measure Adverse Selection? Financial Management 30 (3):77-98.

Vink, Dennis, and André E. Thibeault. 2008. ABS, MBS, and CDO Compared: An Empirical Analysis. Journal of Structured Finance 14 (2):27-45.

Wilmarth, Arthur E. Jr. 2009. The Dark Side of Universal Banking: Financial Conglomerates and the Origins of the Subprime Financial Crisis. Connecticut Law Review 41 (4):963-1050.

Zhang, Tao, Larry A. Cox, and Robert A. Van Ness. 2009. Adverse Selection and the Opaqueness of Insurers. Journal of Risk and Insurance 76 (2):295-321.

Zhang, X. Frank. 2006. Information Uncertainty and Stock Returns. The Journal of Finance 61 (1):105136. 
Figure 1: Growth of CDOs

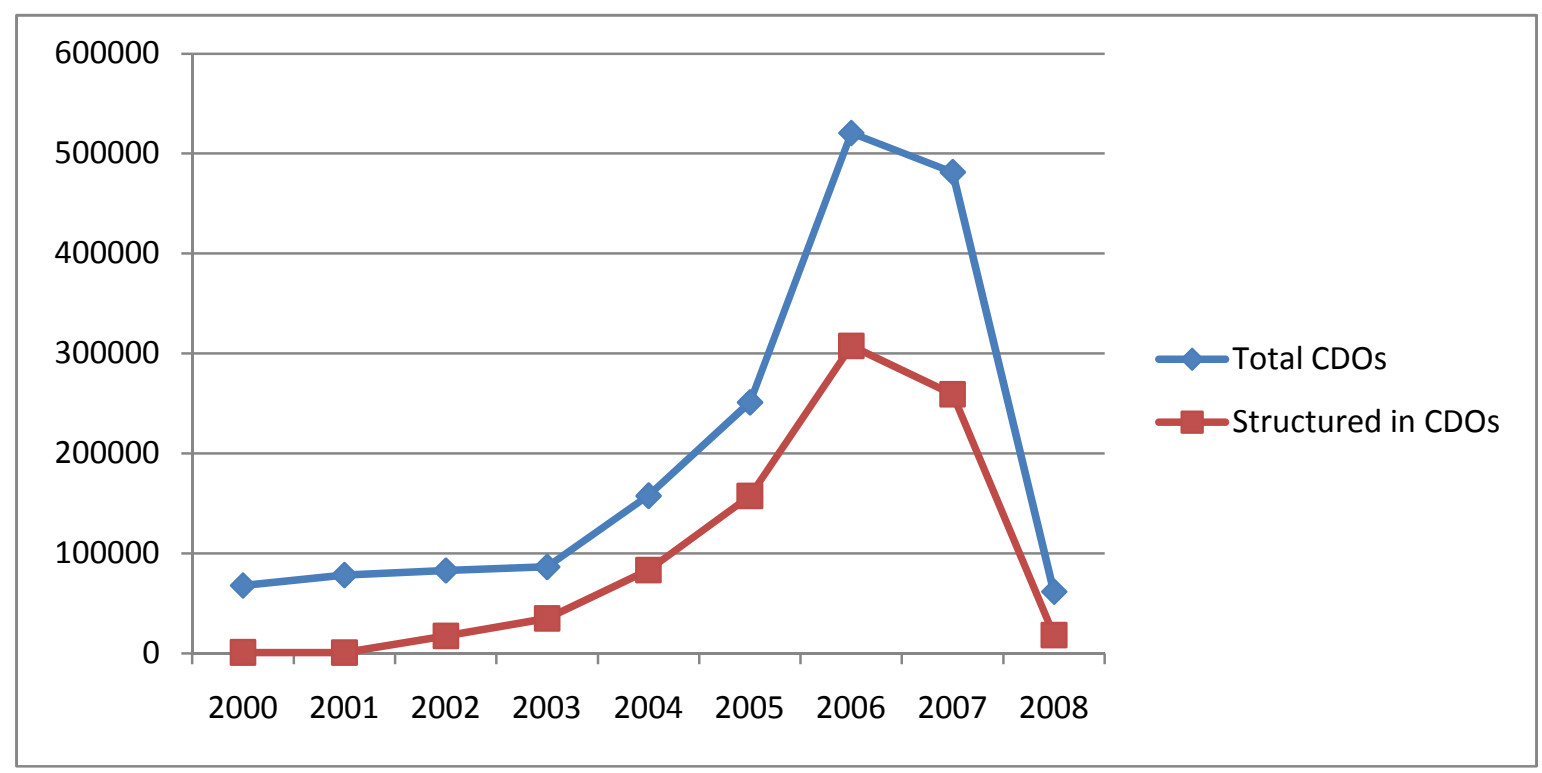

Source: SIGFA.org

Note: Numbers are in millions. "Total CDOs" is total CDO issuance and "Structured in CDOs" is the total structured bonds included in the CDO asset pools. 
Table 1. Summary of Structured Bonds in Insurers’ Assets, Median Value

Panel A. Life-Health Insurance Industry

\begin{tabular}{|c|c|c|c|c|c|c|c|c|c|}
\hline Year & $\mathrm{N}$ & N1 & $\mathrm{N} 1 / \mathrm{N}$ & $\begin{array}{l}\text { Single- } \\
\text { class* }\end{array}$ & $\begin{array}{c}\% \text { Asset } \\
\text { Single }\end{array}$ & N2 & $\mathrm{N} 2 / \mathrm{N}$ & Multi-class* & $\begin{array}{c}\text { \% Asset } \\
\text { Multi }\end{array}$ \\
\hline 1998 & 842 & 484 & $57 \%$ & 99,513 & $4.90 \%$ & 355 & $42 \%$ & 260,264 & $9.19 \%$ \\
\hline 1999 & 751 & 442 & $59 \%$ & 97,728 & $4.97 \%$ & 349 & $46 \%$ & 268,824 & $8.66 \%$ \\
\hline 2000 & 694 & 414 & $60 \%$ & 100,577 & $4.89 \%$ & 327 & $47 \%$ & 297,409 & $9.14 \%$ \\
\hline 2001 & 658 & 416 & $63 \%$ & 134,630 & $4.77 \%$ & 323 & $49 \%$ & 286,719 & $7.96 \%$ \\
\hline 2002 & 618 & 396 & $64 \%$ & 173,343 & $4.85 \%$ & 320 & $52 \%$ & 321,818 & $8.67 \%$ \\
\hline 2003 & 591 & 381 & $64 \%$ & 176,889 & $4.74 \%$ & 302 & $51 \%$ & 360,645 & $9.28 \%$ \\
\hline 2004 & 563 & 371 & $66 \%$ & 207,683 & $4.79 \%$ & 301 & $53 \%$ & 380,383 & $9.76 \%$ \\
\hline 2005 & 539 & 364 & $68 \%$ & 212,994 & $4.09 \%$ & 293 & $54 \%$ & 445,984 & $10.69 \%$ \\
\hline 2006 & 514 & 352 & $68 \%$ & 246,627 & $3.67 \%$ & 284 & $55 \%$ & 715,793 & $11.20 \%$ \\
\hline 2007 & 492 & 340 & $69 \%$ & 215,843 & $4.11 \%$ & 284 & $58 \%$ & 584,698 & $11.75 \%$ \\
\hline 2008 & 468 & 331 & $71 \%$ & 212,917 & $3.78 \%$ & 283 & $60 \%$ & 599,947 & $11.43 \%$ \\
\hline
\end{tabular}

Panel B. Property-Casualty Insurance Industry

\begin{tabular}{llllllllll}
\hline Year & N & N1 & N1/N & $\begin{array}{c}\text { Single- } \\
\text { class* }\end{array}$ & $\begin{array}{c}\text { \% Asset } \\
\text { Single }\end{array}$ & N2 & N2/N & \multicolumn{2}{c}{ Multi-class*\% Asset } \\
Multi
\end{tabular}

Note: * This is industry-aggregated total investment. Numbers are in millions and in 2005 dollars. Data Source: calculated from NAIC database for property-casualty and life-health industry. The calculation includes all companies (insurance groups and unaffiliated single firms) in the industry, regardless of their public trading status. 
Table 2. Summary Statistics of Variables for Regression Analysis

\begin{tabular}{|c|c|c|c|c|c|c|}
\hline Variable & $\mathbf{N}$ & Mean & Median & Min & Max & STD \\
\hline QSPREAD & 1134 & $1.27 \%$ & $0.45 \%$ & $0.01 \%$ & $17.84 \%$ & $2.07 \%$ \\
\hline DISP & 537 & 0.05 & 0.03 & 0.00 & 1.18 & 0.11 \\
\hline PUBSINGLE & 1134 & $4.46 \%$ & $2.42 \%$ & $0.00 \%$ & $45.08 \%$ & $5.38 \%$ \\
\hline PRISINGLE & 1134 & $0.10 \%$ & $0.00 \%$ & $0.00 \%$ & $21.75 \%$ & $0.77 \%$ \\
\hline PUBMULTI & 1134 & $7.38 \%$ & $4.90 \%$ & $0.00 \%$ & $71.07 \%$ & $8.80 \%$ \\
\hline PRIMULTI & 1134 & $0.48 \%$ & $0.00 \%$ & $0.00 \%$ & $11.87 \%$ & $1.09 \%$ \\
\hline PUBMULTID & 1134 & $5.68 \%$ & $2.79 \%$ & $0.00 \%$ & $71.07 \%$ & $8.10 \%$ \\
\hline PUBMULTIO & 1134 & $1.61 \%$ & $0.37 \%$ & $0.00 \%$ & $34.77 \%$ & $2.92 \%$ \\
\hline PRIMULTID & 1134 & $0.15 \%$ & $0.00 \%$ & $0.00 \%$ & $3.97 \%$ & $0.43 \%$ \\
\hline PRIMULTIO & 1134 & $0.32 \%$ & $0.00 \%$ & $0.00 \%$ & $11.87 \%$ & $0.90 \%$ \\
\hline OOPAQUE & 1134 & $5.08 \%$ & $2.06 \%$ & $0.00 \%$ & $55.56 \%$ & $7.52 \%$ \\
\hline PCOPA & 1134 & $54.65 \%$ & $66.44 \%$ & $0.00 \%$ & $100.00 \%$ & $37.39 \%$ \\
\hline LHOPA & 1134 & $14.16 \%$ & $0.00 \%$ & $0.00 \%$ & $100.00 \%$ & $25.20 \%$ \\
\hline FINHOLD & 1134 & 0.21 & 0 & 0 & 1 & 0.4 \\
\hline LASSET & 1134 & 8.37 & 8.21 & 2.79 & 14.47 & 2.25 \\
\hline LEVER & 1134 & 0.76 & 0.78 & 0.01 & 0.97 & 0.15 \\
\hline GROWTH & 1134 & 0.07 & 0.03 & -0.72 & 1.75 & 0.22 \\
\hline LANAL & 1134 & 1.82 & 2.08 & 0.00 & 3.53 & 1.05 \\
\hline LVOL & 1134 & 11.41 & 11.58 & 5.29 & 17.96 & 2.19 \\
\hline LPRC & 1134 & 3.25 & 3.33 & -0.97 & 11.86 & 1.28 \\
\hline LSTD & 1134 & -3.79 & -3.84 & -4.97 & -1.90 & 0.52 \\
\hline
\end{tabular}

Note: Percentages are presented in this table for some variables, but raw numbers are used in the regression analysis for all variables. 
Table 3. Regression Analysis: Privately Placed vs. Publicly Traded Structured Bonds

\begin{tabular}{|c|c|c|c|c|}
\hline & QSPREAD & QSPREAD & DISP & DISP \\
\hline & $1998-2004$ & $2005-2008$ & 1998-2004 & $2005-2008$ \\
\hline \multirow[t]{2}{*}{ PUBSINGLE } & -0.0003 & $-0.0043^{* * *}$ & 0.0779 & 0.0194 \\
\hline & {$[-0.0576]$} & {$[-3.4726]$} & [1.5420] & [0.1996] \\
\hline \multirow[t]{2}{*}{ PRISINGLE } & -0.0254 & $0.0190 *$ & 0.0114 & 0.2664 \\
\hline & {$[-1.3420]$} & [1.8578] & {$[0.0300]$} & {$[0.4795]$} \\
\hline \multirow[t]{2}{*}{ PUBMULTI } & 0.0016 & $0.0027 * *$ & $0.1012 * *$ & $0.2318 * * *$ \\
\hline & {$[0.3345]$} & {$[2.1654]$} & {$[2.5681]$} & [3.1302] \\
\hline \multirow[t]{2}{*}{ PRIMULTI } & -0.0141 & $0.0363 * * *$ & -0.0124 & $0.4921 * * *$ \\
\hline & {$[-0.6315]$} & [8.6612] & {$[-0.0875]$} & {$[2.9024]$} \\
\hline \multirow[t]{2}{*}{ OOPAQUE } & -0.0035 & -0.0019 & -0.0514 & 0.0887 \\
\hline & {$[-0.5648]$} & {$[-1.2938]$} & {$[-1.3863]$} & [1.0729] \\
\hline \multirow[t]{2}{*}{ PCOPA } & -0.0002 & 0.0003 & -0.0034 & -0.0290 \\
\hline & {$[-0.0881]$} & {$[0.6307]$} & {$[-0.3648]$} & {$[-0.6151]$} \\
\hline \multirow[t]{2}{*}{ LHOPA } & -0.0013 & $0.0022 * * *$ & -0.0127 & -0.0199 \\
\hline & {$[-0.5376]$} & [3.9009] & {$[-0.9631]$} & {$[-0.6878]$} \\
\hline \multirow[t]{2}{*}{ FINHOLD } & 0.0013 & -0.0000 & 0.0000 & -0.0186 \\
\hline & [1.2479] & {$[-0.0512]$} & {$[0.0020]$} & {$[-0.9670]$} \\
\hline \multirow[t]{2}{*}{ LASSET } & 0.0007 & 0.0003 & -0.0048 & $0.0539 * * *$ \\
\hline & {$[0.9533]$} & {$[1.2680]$} & {$[-0.9268]$} & [3.2136] \\
\hline \multirow[t]{2}{*}{ LEVER } & -0.0041 & $-0.0015 * *$ & 0.0000 & $0.1121 * * *$ \\
\hline & {$[-1.1990]$} & {$[-1.9791]$} & {$[0.0003]$} & [2.9983] \\
\hline \multirow[t]{2}{*}{ GROWTH } & -0.0006 & $0.0008 * *$ & -0.0169 & $0.0642 * * *$ \\
\hline & {$[-0.3749]$} & [1.9878] & {$[-1.4157]$} & [2.8436] \\
\hline \multirow[t]{2}{*}{ LANAL } & 0.0006 & $-0.0003^{*}$ & -0.0065 & $-0.0537 * * *$ \\
\hline & [1.2919] & {$[-1.8218]$} & {$[-1.3007]$} & {$[-4.7057]$} \\
\hline \multirow[t]{2}{*}{ LSTD } & $0.0028 * * *$ & $0.0003 *$ & -0.0023 & -0.0061 \\
\hline & [4.0704] & {$[1.7126]$} & {$[-0.3170]$} & {$[-0.8480]$} \\
\hline \multirow[t]{2}{*}{ LVOL } & $-0.0012 * * *$ & $-0.0008 * * *$ & $0.0148 * * *$ & $-0.0160 * *$ \\
\hline & {$[-3.5237]$} & {$[-8.2439]$} & [3.8093] & {$[-2.2544]$} \\
\hline \multirow[t]{2}{*}{ LPRC } & $-0.0025 * * *$ & $-0.0015 * * *$ & -0.0036 & $-0.0243 * * *$ \\
\hline & {$[-4.4758]$} & {$[-14.9117]$} & {$[-0.8570]$} & {$[-5.1495]$} \\
\hline $\mathrm{N}$ & 691 & 441 & 315 & 229 \\
\hline Adjusted R2 & 0.965 & 0.987 & 0.979 & 0.754 \\
\hline
\end{tabular}

Note: Firm and year fixed effects are included but not reported here. ${ }^{*}, * *$, and $* * *$ indicate significance at the $10 \%, 5 \%$, and $1 \%$ levels, respectively. Numbers in brackets show t-value. 
Table 4. Regression Analysis: Structured Bonds with Different Rating Categories

\begin{tabular}{|c|c|c|c|c|}
\hline & QSPREAD & QSPREAD & DISP & DISP \\
\hline & $1998-2004$ & $2005-2008$ & 1998-2004 & $2005-2008$ \\
\hline \multirow[t]{2}{*}{ PUBSINGLE } & 0.0008 & $-0.0029 * *$ & 0.0697 & 0.0653 \\
\hline & {$[0.1667]$} & {$[-2.4398]$} & {$[1.2758]$} & {$[0.6465]$} \\
\hline \multirow[t]{2}{*}{ PRISINGLE } & -0.0239 & 0.0156 & -0.0891 & -0.2134 \\
\hline & {$[-1.2782]$} & {$[1.5952]$} & {$[-0.2203]$} & {$[-0.3373]$} \\
\hline \multirow[t]{2}{*}{ PUBMULTID } & 0.0053 & $0.0044 * * *$ & $0.0949 * *$ & 0.1371 \\
\hline & {$[1.0176]$} & {$[3.4262]$} & {$[2.1565]$} & {$[1.2426]$} \\
\hline \multirow[t]{2}{*}{ PUBMULTIO } & -0.0117 & -0.0014 & -0.0480 & -0.0299 \\
\hline & {$[-1.0568]$} & {$[-0.6940]$} & {$[-0.4838]$} & {$[-0.3206]$} \\
\hline \multirow[t]{2}{*}{ PRIMULTID } & -0.1170 & -0.0020 & -0.1449 & 0.4038 \\
\hline & {$[-1.6232]$} & {$[-0.1758]$} & {$[-0.3985]$} & {$[0.7638]$} \\
\hline \multirow[t]{2}{*}{ PRIMULTIO } & -0.0034 & $0.0441 * * *$ & -0.1434 & $1.0319 * * *$ \\
\hline & {$[-0.1449]$} & [9.8534] & {$[-0.8507]$} & {$[5.3142]$} \\
\hline \multirow[t]{2}{*}{ OOPAQUE } & -0.0012 & -0.0016 & -0.0377 & 0.1305 \\
\hline & {$[-0.1982]$} & {$[-1.1716]$} & {$[-0.9513]$} & [1.5163] \\
\hline \multirow[t]{2}{*}{ PCOPA } & -0.0001 & -0.0001 & -0.0028 & -0.0277 \\
\hline & {$[-0.0480]$} & {$[-0.1175]$} & {$[-0.2818]$} & {$[-0.5601]$} \\
\hline \multirow[t]{2}{*}{ LHOPA } & -0.0017 & $0.0022 * * *$ & -0.0116 & -0.0133 \\
\hline & {$[-0.7064]$} & {$[4.0763]$} & {$[-0.8308]$} & {$[-0.4425]$} \\
\hline \multirow[t]{2}{*}{ LIQUID } & 0.0015 & -0.0000 & -0.0031 & -0.0148 \\
\hline & {$[1.4507]$} & {$[-0.0506]$} & {$[-0.4755]$} & {$[-0.7396]$} \\
\hline \multirow[t]{2}{*}{ LASSET } & 0.0010 & 0.0004 & -0.0023 & $0.0417 * *$ \\
\hline & [1.3183] & {$[1.4594]$} & {$[-0.4107]$} & [2.3915] \\
\hline \multirow[t]{2}{*}{ LEVER } & -0.0049 & -0.0012 & -0.0022 & $0.1386^{* * *}$ \\
\hline & {$[-1.4409]$} & {$[-1.5512]$} & {$[-0.0598]$} & [3.5061] \\
\hline \multirow[t]{2}{*}{ GROWTH } & -0.0000 & $0.0008 *$ & -0.0165 & $0.0585 * *$ \\
\hline & {$[-0.0195]$} & [1.8713] & {$[-1.2937]$} & {$[2.4765]$} \\
\hline \multirow[t]{2}{*}{ LANAL } & 0.0007 & -0.0002 & $-0.0092 *$ & $-0.0503 * * *$ \\
\hline & [1.5859] & {$[-1.6131]$} & {$[-1.7196]$} & {$[-4.2462]$} \\
\hline \multirow[t]{2}{*}{ LSTD } & $0.0028^{* * *}$ & $0.0003 * *$ & -0.0035 & -0.0107 \\
\hline & [4.1081] & [2.1567] & {$[-0.4443]$} & {$[-1.4211]$} \\
\hline \multirow[t]{2}{*}{ LVOL } & $-0.0013 * * *$ & $-0.0008 * * *$ & $0.0153 * * *$ & $-0.0159 * *$ \\
\hline & {$[-3.6957]$} & {$[-8.1328]$} & [3.6777] & {$[-2.1524]$} \\
\hline \multirow[t]{2}{*}{ LPRC } & $-0.0027 * * *$ & $-0.0014 * * *$ & -0.0040 & $-0.0247 * * *$ \\
\hline & {$[-4.9599]$} & {$[-14.4874]$} & {$[-0.8792]$} & [-4.9191] \\
\hline $\mathrm{N}$ & 692 & 440 & 299 & 233 \\
\hline Adjusted R2 & 0.966 & 0.988 & 0.977 & 0.741 \\
\hline
\end{tabular}

Note: Firm and year fixed effects are included but not reported here. *, **, and *** indicate significance at the $10 \%, 5 \%$, and $1 \%$ levels, respectively. Numbers in brackets show t-value. 